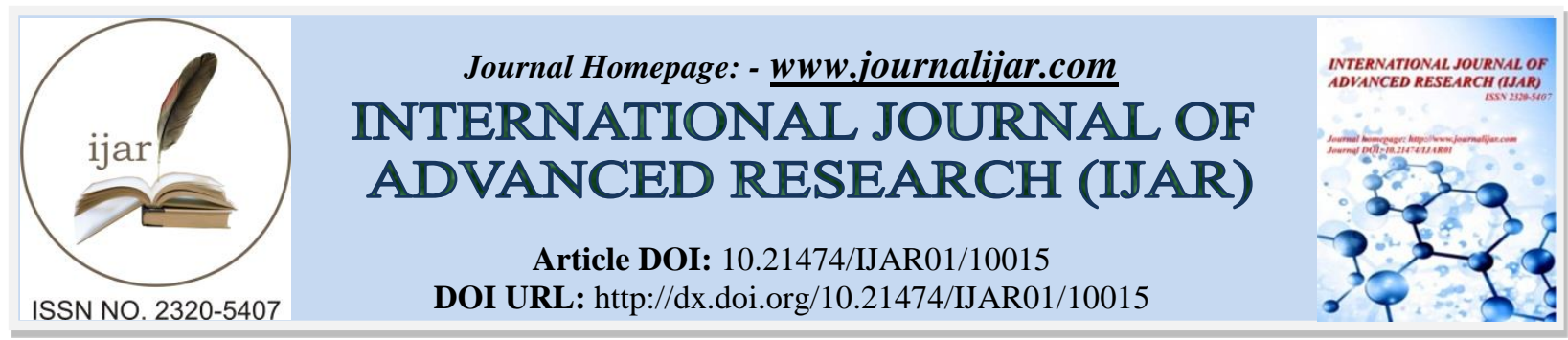

RESEARCH ARTICLE

\title{
INSTITUTIONAL STRUCTURES AND THEIR EFFECTS ON SKILLS DEVELOPMENT IN YOUTH POLYTECHNICS IN MURANG'A, KIRINYAGA AND NAIROBI CITY COUNTIES, KENYA.
}

1. Phd Student Kenyatta University.

2. Kenyatta University.

\section{Manuscript Info}

\section{Manuscript History}

Received: 08 September 2019

Final Accepted: 10 October 2019

Published: November 2019

Key words:-

Youth polytechnics (YPs), skills development, institutional structures.

\begin{abstract}
Availability of adequate and relevant structures is crucial for the governance of TVET institutions. The purpose of this study was to investigate and assess the institutional structures and their effects on skills development in public youth polytechnics in Murang'a, Kirinyaga and Nairobi city counties. The objectives of the study were to assess the youth polytechnics' various institutional structures and their effects on skills development and determine the institutional capacity development requirements. The Cross-sectional survey design was used in this study. The study targeted all the 61 Public Youth Polytechnics in Murang'a, Kirinyaga and Nairobi city counties. The stratified sampling method was used to select 18 polytechnics that formed the study sample. The Managers, Heads of Department, District Youth Training Officers and primary school head teachers were respondents in the study. Data collection instruments included questionnaires, interview and observation schedules. Descriptive analysis was used to analyze the data which was presented using both tabular and graphical formats. The study established various gaps in the institutional structures that hinder the development of appropriate skills in youth polytechnics. These included inadequate policy related to Board of management and Parents Associations, inadequate capacity and low involvement of the existing structures. These gaps led to poor management and inadequate training in youth polytechnics. The study recommends legal and policy measures including review of existing laws to enhance institutional structures of youth polytechnics for appropriate skills development.
\end{abstract}

Copy Right, IJAR, 2019,. All rights reserved.

\section{Introduction:}

According to Common Wealth (2013), availability of adequate structures and frameworks is a crucial issue for governance of Technical Vocational Education and Training (TVET). Appropriate structures are important in the implementation of policy. Further GIZ 2014, opines that various structures including departments provide for a deeper participation, widened responsibilities for the teaching staff and therefore a better motivated and progressive community of teachers and students. Departments are also crucial in determining their requirements. The principal and the heads of departments are supposed to manage the human resource in the most effective manner so that the staff works well in the best interests of the institution and in their own interest. However organizational structures 
depend on the legal framework and therefore it's necessary to align the framework on the organizational needs of the institutions.

Africa Union (2018) further asserts that TVET operates in an environment that lacks harmony in the implementation of the programmes. TVET governance in most African countries usually falls under the oversight of the ministries responsible for education or technical education and labour or employment. However, in some specialised programmes for example in agriculture, health and transport, oversight falls under the supervision of the relevant ministries. Despite the large number of training programmes, TVET in many countries is marginalized both in terms of enrolment and number of institutions. According to Republic of Kenya (2012d), there are multiple government departments, agencies and levels with responsibility for TVET policies in Kenya. Lack of a stable framework has been manifested in frequent changes in ministries that manage YPs and various aspects governed by different sectoral legislation (Yungungu, Maleche, Ndurumo, \& Ogolla (2014), Republic of Kenya (2006a). (Republic of Kenya 2007c).,

The functionality of training institutions depends on governance and management structures. Such structures should promote cohesion, nurture accountability and provide leadership (Republic of Kenya (e) 2007). In Kenya the YPs sector is characterized by lack of a stable institutional framework to guide planning, administration and management roles of the different stakeholders (Republic of Kenya 2006a). The lack of a stable institutional framework to guide planning, administration and management roles of the different stakeholders in YPs including managers, boards of management (BOMs) and parents' associations (PAs), has affected skills development in YPs. According to Simiyu 2009, in a study on revitalizing a technical training institute in Kenya, the manager of the institution plays a great role in not only mobilizing resources but also setting targets and relating them to the vision and mission of the institution. According to Walters (2007), understanding the existing institutional framework ensures that strategies proposed would lead to the desired changes. There is need therefore to recognize and actually deal with institutional impediments or make use of opportunities offered by the existing situation. The study therefore sought to provide necessary information to inform the formulation of a relevant and sustainable capacity development response and achieve relevant youth training and skills development in the three counties.

\section{Purpose and Objectives of the Study.}

The purpose of this study was to investigate and assess the institutional structures and their effects on skills development in public YPs in Murang'a, Kirinyaga and Nairobi city counties.

\section{The study was guided by three objectives:}

1. Examine the various institutional structures in youth polytechnics

2. Determine the effects of the institutional capacity gaps on skills development

3. Determine the institutional capacity development requirements for Youth Polytechnics.

\section{Literature Review}

Acquisition of appropriate skills for industry and the labour market has been identified as solution to youth unemployment and related challenges. According to Balwanz (2012) youth skills development, poverty and unemployment are major global issues of concern. Many countries are fast adopting new and emerging technologies in industry that require a skilled workforce. (Ismail \& Razali, 2013). However, Africa Union (2018) asserts that in Africa, TVET is faced by various challenges including inadequate financing, poor management and ill-adapted organizational structures.

In Kenya one of the main challenges facing TVET is the failure to respond to the demands of the job market and the needs of industry. In the YP sector this is mainly due to poor capacity to develop requisite skills as demanded by industry. (Republic of Kenya, (2011e). A study on the Effectiveness of youth polytechnics in training the youth for employment in Machakos District, Kenya in 2014 concluded that to a great extent, YPs were not effective in training the youth for employment. (Yungungu, Maleche, Ndurumo \& Ogolla, 2014). The YPs therefore required aligning themselves with the needs of employers, the national economy and generally the global trends of technology and industry.

According to Republic of Kenya (2012d), lack of clear policy has been manifested in the frequent changes of the parent ministries. Initially YPs were under the Ministry of Culture and Social Services, but were later moved to the Ministry of Technical Training, before moving to the Ministry of Labour and Human Resource Development and 
later to the ministry of youth affairs and sports (Republic of Kenya 2006a) before being transferred to the ministry of education, science and technology. Currently YPs are under county governments. According to the Basic Education Act, 2013, the county education board in consultation with the county governments would oversee the operations and management of the YPs. These changes have caused instability and inconsistencies in policy development and implementation. The multiple TVET management structures and different supervisory bodies and organisations lead to various inefficiencies. These include duplicated efforts in TVET provision and the lack of harmony in development of policies and other initiatives. The TVET sector operates in an environment of poor funding and inappropriate organizational structures (Hashim \& Afeti, 2009).

The terms of employment including remuneration are important determinants of the effectiveness of institutional structures. In a study on the effectiveness of youth polytechnics in training the youth for employment in Machakos, Kenya; Yungungu, Maleche, Ndurumo, \& Ogolla (2014) established that instructors were poorly remunerated and thus affected the effectiveness of youth training in YPs. According to Erika \& Teodoras (2013) in a study on Investigations of the Advantages and Disadvantages of Temporary Employment further established that temporary employees are generally paid lower wages than the permanent employees, hence commitment to the place of work and values decrease while their zeal for search of new jobs increases. Employees' turnover thus increases. Temporary employment also causes uncertainty and the employees feel unsettled in their careers. This is especially due to lack of job security and lack of various allowances including retirement, house, commuter, health and safety insurance that are usually enjoyed by their counterparts who are employed on permanent terms.

\section{Research Design and Methodology: -}

This study employed the cross-sectional survey design targeting a population of 1140(N) comprising of District Youth Training Officers (DYTOs), YP managers, Heads of Departments (HODs) and Primary School Head Teachers. The study used stratified, purposive and simple random sampling techniques to obtain a sample of 114(n) respondents from the target population. The study was carried out in 18 YPs. Questionnaires and interview guides were used to collect data from the respondents. The data was analyzed using SPSS and presented in tables, figures and narrations.

\section{Research Findings and Discussion: -}

The study generated both quantitative and qualitative data. The data was obtained through the use of questionnaires, interview schedules and observation schedules. The total sample was 114 while 109 was reached. Table 1 shows the total number of targeted respondents and those reached.

Table 1:-Response Rate

\begin{tabular}{|l|l|l|}
\hline Interview Schedule and Questionnaire & $\begin{array}{l}\text { Targ } \\
\text { et }\end{array}$ & $\begin{array}{l}\text { Reache } \\
\text { d } \\
\text { Respon } \\
\text { se Rate }\end{array}$ \\
\hline Youth Polytechnic Managers & $\begin{array}{l}18 \\
100 \%\end{array}$ \\
\hline DYTOs & 18 & 5 \\
& $83.3 \%$ \\
\hline Head of departments & 50 \\
\hline Primary School head teacher Schedule & 54 & $53.0 \%$ \\
\hline Total & 36 & 36 \\
& $95.7 \%$ & $100 \%$ \\
\hline
\end{tabular}

The data collected was cleaned and then analyzed. The quantitative data from the questionnaires was analyzed using the Statistical Package for Social Sciences (SPSS) computer Program. The qualitative data from the interview schedules was analyzed by identifying the main themes, assigning codes to the themes and classifying the responses. The data was then analysed thematically using a research matrix display. 


\section{Policy Framework}

The study established that the YPs lacked effective regulatory mechanisms to monitor, evaluate and enforce regulations and curriculum implementation in order to assure quality in training. Technical and Vocational Education and Training Authority (TVETA) was mandated to inspect TVET institutions while the Directorate of Quality Assurance and Standards was mandated to ensure standards in basic education institutions. It was not clear which of these quality assurance institutions should be involved in the YPs. The managers were of the opinion that lack of a quality assurance and standards mechanism in YPs compromised on the quality of skills development in the institutions. The multiple government departments, agencies and levels responsible for TIVET policies in Kenya led to disharmony in development of TVET. This was identified as a factor that further undermined the adequacy of the policy framework in skills. For example, while other sectors of TVET were managed by agencies under the national government, YPs were managed by the various county governments whose policies were not harmonized.

The YPs also lacked a clear policy on the appointment of BOMs especially after devolution. One manager reported that the BOM had expired but no regulations had been developed by the county government on the process of appointing a new one. The BOMs were appointed with reference to the provisions of the Education Act Chapter 211 (1980). This was informed by the fact that the National Policy for Youth Polytechnics and Vocational Training Sector, 2006 recognised YPs as basic education institutions and therefore under the then Education Act Chapter 211 (1980). However, the relevance of the policy for YPs became unclear after devolution when YPs were placed under county governments. The Education Act Chapter 211 (1980) was repealed and replaced by the Basic Education Act 2013.

The Basic Education Act (2013) was clear on appointment, membership and even functions of BOMs for basic education institutions. This function was delegated to county education boards. The TVET Act (2013) also stipulated membership and governance procedures for boards of governors for training institutions. Although YPs are also training institutions, the managers were not sure which law was applicable in appointing BOM members especially because the YPs, although being basic learning institutions were devolved to the counties.

\section{Terms of Employment}

The study sought to establish the terms of employment of the YP managers, DYTO's, Heads of department and instructors. The study established that $77.8 \%, 100 \%$ and $44.0 \%$ of the Youth Polytechnic managers, DYTO's, and HODs respectively were permanent and pensionable. The study also established that $24 \%$ of the HODs were on temporally terms of employment. Only $35.56 \%$ of the Instructors were on permanent and Pensionable terms while $53.33 \%$ of them were on contract and $10.1 \%$ were on temporary terms. Appointment of temporary employees as managers of the YPs, though in a few institutions, was a drawback to effective management of the YPs. The managers on temporary terms reported that they lacked control over the instructors and HODs who were employed on permanent terms with higher qualifications and salary. The county governments could also not directly discipline the managers as they were employees of the BOMs.

According to Erika \& Teodoras (2013), temporary employees are generally paid lower wages than the permanent employees, hence commitment to the place of work and values decrease while their zeal for search of new jobs increases. Employees' turnover thus increases. Temporary employment also causes uncertainty and the employees feel unsettled in their careers. This is especially due to lack of job security and lack of various allowances including retirement, house, commuter, health and safety insurance usually enjoyed by their counterparts employed on permanent terms,

The terms of employment of managers and instructors failed to consider some management principles, for example, Henry Fayol's principles of management. According to Uzuegbu \& Nnadozie (2015), Fayol's principles of management are still relevant to organizations' management and administration. Management researchers over the years opined that the 14 principles of management propounded by Fayol is what developed into today's management and administration. According to the principle of authority for example, managers should have authority in order to command subordinates to perform jobs while being accountable for their actions. Thus, Fayol believed that since a manager must be responsible for his duties, he should as well have authority to enable him to perform his duties effectively. Some managers in YPs however had their authority undermined by their temporary or contract terms of employment compared to some instructors who worked under them but employed on permanent and pensionable terms and enjoying higher salaries and allowances. Another Principle relevant to the findings of the study was unity of command. According to the principle, employees should receive orders from and report to one 
authority. However, in YPs where managers were employees of BOMs, instructors signed performance targets with DYTO's. The managers reported that their authority was further undermined when instructors were assessed by the DYTOs who were not the immediate supervisor at the YP level.

The Payment of staff salaries in YPs undermined the principle of remuneration. According to the principle, the salary should be fair to both staff and management and no one should feel disadvantaged. The salary of each employee must be legitimate and reasonable. The person appointed as the supervisor should earn more than the juniors due to the responsibilities associated with the position. However, the DYTOs reported that some instructors who were employees of the county governments earned a higher salary than the managers and HODs who worked under BOMs thus further eroding the confidence and authority of the managers. In a study on Effectiveness of Youth Polytechnics in Training the Youth for Employment in Machakos District, Kenya, Yungungu, Maleche, Ndurumo \& Ogolla, (2014) established that poor remuneration led to demoralization and demotivation in public YPs.

Designation and Nature of Employment of the Non-Teaching Staff

Table 2 shows the area of operation of the non-teaching staff.

Table 2:-Designation and Terms of Employment of the Non-teaching staff

\begin{tabular}{|rl|l|l|}
\hline D) & Watchman & Terms of Employment & Percent (\%) \\
\hline 2) & Cook & 9 & 40.54 \\
\hline 3$)$ & Accounts clerk & Contract & Contract/Casual/Temporary \\
\hline 4$)$ & Grounds man & Contract/Casual & 10.81 \\
\hline 5) & Care taker & Contract & 8.12 \\
\hline 6$)$ & Secretary & Contract & 5.41 \\
\hline 7$)$ Receptionist & Contract & 5.41 \\
\hline 8$)$ & Cooks & Contract/Casual/Temporary & 2.70 \\
\hline 9$)$ & Storekeeper & Contract & 24.32 \\
\hline Total & & 2.7 \\
\hline
\end{tabular}

Among the Non-teaching staff $40.54 \%$ and $10.81 \%$ were watchmen and accounts clerks respectively. There were $5.14 \%$ caretakers, $5.15 \%$ secretaries, $8.12 \%$ grounds men, $2.7 \%$ store keepers, $2.7 \%$ receptionist and $24.32 \%$ cooks. Most of the Non-teaching staff were on Contract with a few employed as casuals and on temporary basis. Majority $(81 \%)$ of the non-teaching staff were employed on contract basis, $5.4 \%$ were casuals and $13.5 \%$ were employed on temporary basis.

Considering the small number of the non-teaching staff it was evident that most of the YPs were understaffed or lacked crucial staff in some areas. For example, there were 18 YPs visited with only 15 watchmen. This was a security lapse in the institutions as nobody was left in these institutions after class hours (5.00 p.m.) and most of the time when the institutions were closed for holiday. Only 4 YPs had accounts clerks. Considering that the managers were not experts in issues of financial management, the YPs were exposed to financial mismanagement. This would consequently impact on the quality of skills development as funds meant for relevant equipment and facilities could be mismanaged due to lack of requisite skills in financial management.

\section{Boards of Management}

All public learning institutions in Kenya are required by law to be managed by Boards of Management (BOMs) The Basic Education Act, 2013 and the TVET Act, 2013 stipulate that basic and TVET institutions be managed by BOMs. Among other functions the BOMs are to ensure and assure the provision of required physical facilities for the institution; ensure education and training in the institutions was done according to the law; ensure standards, quality and relevance in education and training in the institutions; managing institutions' property; development and implementation of strategic plans and recruitment and management of staff. The BOMs were therefore relevant in skills development as they influenced key functions including provision of equipment and facilities and recruitment of relevant staff among other tasks that impacted on skills development in the YPs. 
The study established that $94 \%$ of YPs sampled had BOMs. However, according to the managers there were various challenges related to BOM in the YPs that rendered their performance ineffective. These included inadequate finance and therefore according to the managers, the institutions would not afford to facilitate the operations of the BOMs including allowances for meetings. Some members therefore failed to attend crucial meetings that affected skills development in YPs. The managers indicated that the BOM members lacked management skills and had low academic qualification. Partnership between the YPs and stakeholders, resource allocation and monitoring of the training standards was hampered by lack of effective BOMs. According to the managers, most of the BOM members had little knowledge or no exposure about skills development in YPs. The managers reported that that most educated people turned down nomination to membership of YPs Boards of Management. This was especially as a result of the negative attitude about YPs. There was also no organized BOM induction or in-service courses.

The managers further indicated that there were vested interests and political interference that further affected the performance of BOMs in YPs. The failure to appoint BOMs in new YPs or those where terms had expired especially after devolution compounded the problem of vested interests. One YP manager reported that the BOM had expired but the county government had not commenced the process of appointing a new one. Due to these factors most BOMs were ineffective and therefore lacked capacity to manage the YPs. This denied the YPs the vital contribution of the BOM in terms ensuring provision of required equipment facilities and the effectiveness and efficiency in the management of the institution. This consequently affected quality of training and thus the skills acquired. Although BOMs were relevant to skills development, these shortcomings affected the performance of their duties and thus inability to influence relevant training.

\section{Parents Association}

Figure 1 shows the parents involvement in the management of YPs

Figure 1:-PAs involvement in the management of YPs

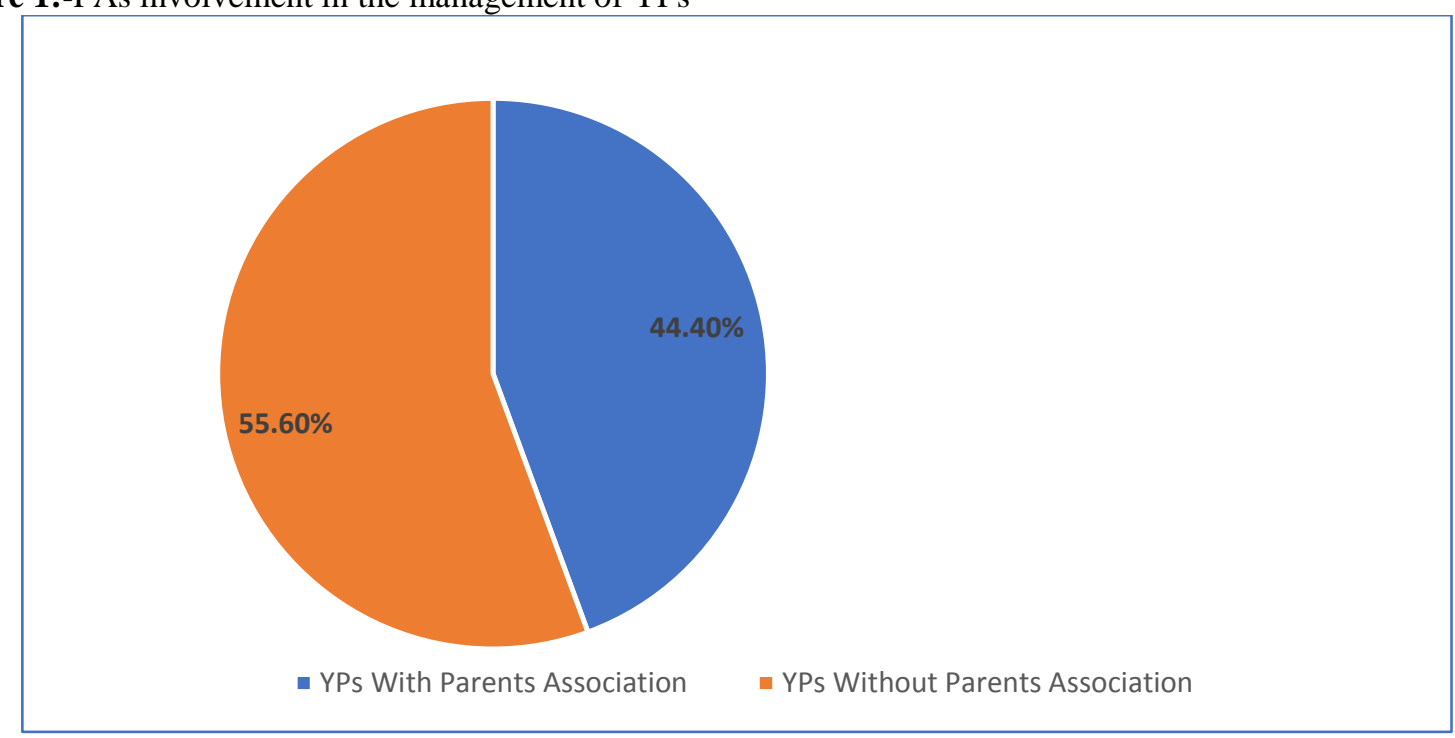

Majority (55.60\%) of YPs did not have (PAs) Parents' Association Among the youth polytechnics sampled only $22.2 \%$ had organized capacity building training or workshops for the management body. Some of the workshops were organized by partners and well-wishers especially NGOs. However, the YPs had no regulations on appointment and operations of PAs.

Low or lack of parents' participation in management of YPs denied the institutions the benefits associated with parental involvement. In a study on the Involvement of Parents in the Education of their Children in Zimbabwe's Rural Primary Schools: The Case of Matabeleland North Province, Mafa \& Makuba (2013) established that parental involvement enhances quality education because the parents motivate the learners and also helps the school to achieve set objectives. Parents' involvement enhances communication and provides a platform to iron out any issues that may otherwise lead to misunderstandings. Parents Associations were therefore viewed as relevant stakeholders in skills development. However even in cases where YPs had PAs, the managers reported that the parents lacked 
capacity as most of them had no basic education or training and thus were unsuitable to perform their duties as members of PAs. HODs further claimed that educated parents never took their children to YPs. Although PAs were relevant in skills development, majority of the YPs did not have the parent's body and where available, they were reported to be ineffective.

The study also analysed trainees participation in YP management.

Figure 2:-Trainee Leadership

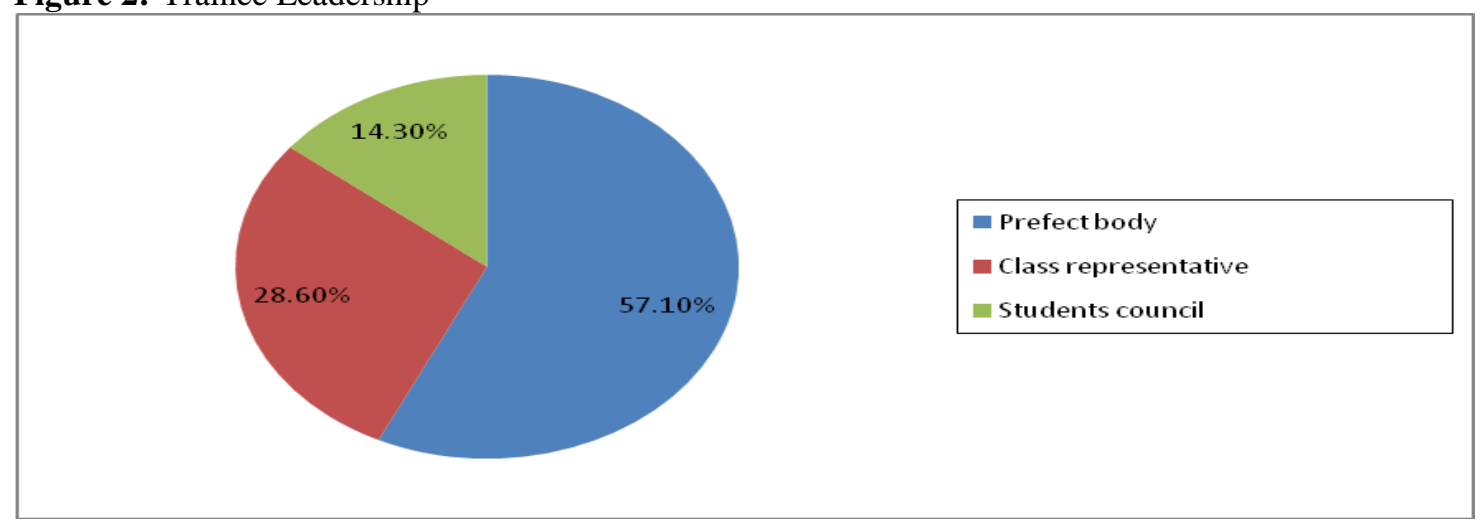

Figure 2 shows that, over half of the institutions had a prefect body and $28.6 \%$ had class representative for each trade. The trainees' leadership role was to collect views from students and present them to the manager/instructors. However, there were no regulations on appointment and operations of trainee leadership.

In a study on Student Engagement in Learning and Teaching Quality Management, A Study of UK Practices, commissioned by the Quality Assurance Agency, Velden, Botas, Naidoo, Lowe \& Pool (2013) established that involvement of student leadership in management help impacts positively on the institution's development. Student engagement not only encourages dialogue between the management ant the learners but also ensures that their ideas are included in shaping institutional policies at all levels. Although trainee leadership was found to be relevant in YP management, lack of policy guidelines on appointment and engagement of the trainees denied the YPs a uniform and consistent system of engaging them in the management of the institutions.

\section{Heads of Departments (HODs)}

The study established that Thirty $34 \%$ of the HODs were highly involved in the management of finances since the YPs lacked bursars. However, they were mainly involved in budgeting and not the actual financial processes of the YPs. Twenty two percent indicated that their involvement was low since the finances were purely managed by the BOM. In a study on the Effects of Teacher Turnover Rates, Rafferty (2002) established that teachers' morale can be strengthened and sustained by empowering them through involvement and support in decision making about policies and practices and recognizing their ability.

\section{Nature of Employment}

The nature of employment of the instructors and managers and their job groups clearly showed lack of defined professional and career progression. For example, 33.3\% of the managers did not have job groups and only $11.1 \%$ were in job group M, the highest in the YPs sampled. Majority of the instructors, HODs and managers who had job groups were in job group $\mathrm{H}$, the lowest category. The managers and HODs also decried lack of a scheme of service unlike their counterparts who were technical teachers employed by the Teachers Service Commission (TSC). The TSC scheme of service had established six grades in the Trained Diploma Technical Teacher cadre and seven grades in the Lecturers cadre. Untrained Diploma Technical Teacher entered the service at job group ' $\mathrm{H}$ ' while the trained Diploma Technical Teacher entered the service at job group ' $\mathrm{J}$ ' and could eventually progress to Principal Trained Diploma Technical Teacher job group ' $\mathrm{N}$ '. The lecturers' cadre entered at Assistant lecturer job group ' $\mathrm{K}$ ' and could eventually progress to Chief Principal Lecturer job group 'R'. (TSC, 2007).

The instructors, HODs and managers employed by the BOMs and county governments lacked a scheme of service to allow the establishment of a defined career structure which would encourage recruitment and retention of qualified 
and competent technical teachers and lecturers in the technical teaching profession. Lack of a scheme of service and the low job groups of the managers and instructors was also associated with low salaries. According to Kigwilu \& Githinji (2015) poor remuneration of instructors leads to low motivation and consequently affect the general their output in skills development. Low or lack of job satisfaction could therefore further impact on the process of skills development. This study established that most YP instructors had low pay and benefits and inferior terms of employment compared to their counterparts employed by the TSC. According to managers this led to low morale to implement the new curriculum which was demanding and complex in terms of effort and skill to accomplish, deal with, or understand.

\section{Conclusions and Recommendations: -}

The study established that majority of the YPs had management structures in place but they were rendered inadequate due to various challenges. The appointment of the BOMs was also considered irregular as it was neither done according to any of the existing legal framework that guided the appointment of BOMs in basic institutions of learning and middle level colleges. Some of the BOMs and PAs had members who lacked minimum education and training. The YPs also lacked regulations for appointment and operations of the BOMs. Lack of appropriate legislation to guide the management of YPs after devolution led to various challenges related to appointment of BOMs, PAs and managers of the YPs.

Although the institutional structures were relevant, they lacked the necessary formal regulations backed by legal and policy guidelines. The structures were also affected by appointment of staff especially managers on temporary terms, poor remuneration and lack of job security. The YPs also lacked staff in crucial areas like watchmen and accounts clerks. Secondly, the findings that the instructors including some HODs and managers were deficient in terms of academic and professional qualifications and that the BOMs and PAs as constituted did not conform to any existing legal framework, rendered the structures and capacities inadequate and to a great extent unsuitable to the duties they were performing and therefore inadequate to skills development in YPs

\section{Recommendations}

The government of Kenya should adopt a national approach to TVET policy development and implementation under one ministry and establish appropriate structures and agencies to ensure harmony in policy implementation. The management of the YPs should be reverted to the national government like other sectors of education and training in Kenya. This would ensure uniformity and harmony in TVET policy development and review.

The management of YPs should be harmonized through review of the Basic Education Act, 2013 and TVET Act, 2013. This should include matters of structures and governance, stipulating the place and role of various management structures in YPs.

\section{Bibliography:-}

1. African Union. (2018). Continental Strategy for Technical and Vocational Education and Training (TVET) to Foster Employment, Addis Ababa, Ethiopia

2. Erika S. \& Teodoras T. (2013). Investigation of the Advantages and Disadvantages of Temporary Employment, Siauliai University, Vilnian

3. GIZ (2014). Hand Book Management of TVET, GIZ Retrieved July 26, 2019 from www.bmz.de

4. Hashim, A. W. (Dr.) \& Afeti,G. (2009). Revitalizing TVET Provision in ECOWAS Countries, UNESCO, Abunja.

5. Ibuathu, C., \& Thiaine, S., (2013) The Impact of Vocational Training for Rural Development: A Case Study of Youth Polytechnics in Nyambene District, Kenya International Journal of Human Resource and Procurement Vol.1, Issue 5, 2013 Retrieved September $2^{\text {nd }} 2015$ from http://www.ijsse.org

6. Ismail, A \& Razali, H. (2013) Issues and Challenges of Technical and Vocational Education \& Training in Malaysia for Knowledge Worker Driven, ResearchGate, Hussein Onn University of Malaysia, Batu Pahat.

7. Kigwilu, P., \& Githinji, J (2015). Teacher Factors Influencing Effective Implementation of Artisan and Craft Curriculum in Community Colleges in Kenya, American Scientific Research Journal for Engineering, Technology, and Sciences, Retrieved September $30^{\text {th }} 2017$ from http:asrjetsjournal.org

8. Mafa, O., \& Makuba, E., (2013.) The Involvement of Parents in the Education of their Children in Zimbabwe's Rural Primary Schools: The Case of Matabeleland North Province, Journal of Research \& Method in Education, Volume 1, Issue 3 (Mar. -Apr. 2013) Retrieved October 3, 2017 from www.iosrjournals.org 
9. Republic of Kenya, (2019). Sessional Paper No. 1 of 2019 on A Policy Framework for Reforming Education and Training for Sustainable Development in Kenya, Nairobi

10. Republic of Kenya (a) (2018). Kirinyaga County Integrated Development Plan 2018-2022, Kutus, Kenya

11. Republic of Kenya (b) (2018). Murang'a County Integrated Development Plan 2018-2022, Murang'a, Kenya

12. Republic of Kenya (c) (2018). Nairobi County Integrated Development Plan 2018-2022, Nairobi, Kenya

13. Republic of Kenya (2015). Human Resource Policies and Procedures Manual for The Public Service, Public Service Commission of Kenya, Nairobi

14. Republic of Kenya (a) (2014). National Education Sector Plan 2013-2018, Nairobi

15. Republic of Kenya (b) (2014). Kenya National Qualifications Framework Act, 2014, Nairobi

16. Republic of Kenya. (a). (2013).The Basic Education Act, 2013,Nairobi.

17. Republic of Kenya. (b). (2013).The Technical and Vocational Education and Training Act, 2013, Nairobi.

18. Republic of Kenya (a).(2012). Kirinyaga County Development Profile, Kerugoya.

19. Republic of Kenya (b).(2012). Nairobi County development Profile, Nairobi.

20. Republic of Kenya (c). (2012). Sessional Paper No 14 of 2012, On Reforming Education and Training Sectors in Kenya, Nairobi.

21. Republic of Kenya (d). (2012) Technical and Vocational Education and Training (TVET) Policy, Nairobi

22. Republic of Kenya (c). (2011). Murang'a County Development Plan, 2012 - 2017, Murang'a.

23. Republic of Kenya (e). (2011). Skills Gap Analysis for Graduates of Youth Polytechnics, Vocational Training Centers and Out-Of-School Youth, Nairobi.

24. Republic of Kenya. (2010). Constitution of Kenya 2010, Nairobi

25. Republic of Kenya (b).(2007). Kenya Vision 2030, Nairobi.

26. Republic of Kenya (c).(2007). MOYAs Strategic Plan 2007-2012, Nairobi.

27. Republic of Kenya (a). (2006). National Policy for Youth Polytechnics and Vocational Training Sector, Nairobi.

28. Republic of Kenya(b). (2006). Kenya National Youth Policy, Nairobi.

29. Republic of Kenya (b). (2005). Sessional Paper no.1 of 2005, A Policy Framework for Education, Training and Research, Nairobi.

30. Republic of Kenya (c). (2005). Kenya Education Sector Support Programme, 2005-2010, Nairobi.

31. Simiyu, J. W.(2009). Revitalizing a Technical Training Institute in Kenya, A case Study of Kaiboi Technical Training Institute, Eldoret, Kenya, UNEVOC, Bonn

32. TSC. (2007). Revised Scheme of Service for Technical Teachers and Lecturers, TSC, Nairobi

33. Velden, G.M., Botas, P.C., Naidoo, R. Lowe, A. \& Pool, A.D., (2013) Student Engagement in Learning and Teaching Quality Management,University of Bath

34. Uzuegbu C. P., \& Nnadozie C.O.(2015) Henry Fayol's 14 Principles of Management: Implications for Libraries and Information Centres, Journal of Information Science Theory and Practice Retrieved September 21, 2017 from http://www.jistap.org

35. Walters, H. (2007). Capacity Development, Institutional Change and Theory of Change: What do we mean and where are the linkages, Wageningen University Research, Wageningen Retrieved October 4, 2013 from www.wi.wur.nl.

36. Yungungu. A., Maleche. K.M., Ndurumo. M.M, \& Ogolla. B., (2014) Effectiveness of Youth Polytechnics in Training the Youth for Employment in Machakos District, Kenya, International Journal of Social Sciences and Entrepreneurship Vol.1, Issue 9, Retrieved July 42019 from www.ijsse.org. 